\title{
The Contributions of the University Library to the War Effort: The Possible vs. the Actual
}

Mr. Knollenberg, librarian of Yale University, delivered this, the second of three papers, before the University Libraries Section of A.C.R.L., June 24, 1942.

$\mathrm{I}^{\mathrm{N}}$ H HS LETTER ASKING ME to present this paper, Mr. Leupp said that he wished me to speak as a representative of the eastern coast. I should like to do so if I could be sure that what I am about to say would be representative of the views of the librarians east of the Alleghenies. But since I am not familiar with their views, I shall have to content myself with expressing the hope that what I say is representative.

Turning first to the actual, the contributions that the Yale University Library has made or is making to the war effort fall roughly into two broad classes- technical assistance and propaganda.

The industries of Connecticut were among the first to be called upon to step up war production and they of course promptly responded. Several of these industries asked for permission to draw on the resources of the Yale University $\mathrm{Li}$ brary for books in the fields of chemistry, technology, and others directly related to war industries. We have not only lent such books in considerable numbers but have given precedence to the demands from war industries over our own professors and students and shall continue to do so. We have also had a number of demands for books in the field of geography from the Army Intelligence, and these, of course, have been promptly furnished.

Perhaps our most important contribution has been in the building up of our extensive war collection. Shortly after the outbreak of World War II in September I939 we got in touch with Yale men throughout the world and asked them to send to us every bit of material bearing on the war they could get hold of, whether in the nature of technical volumes and pamphlets or propaganda literature. The library was unable to get a special appropriation for this, and we therefore had to say that we could only pay for the cost of shipment of the material, not for any cost of acquisition. The collecting of the material was under the direct charge of Russell Pruden, of the library staff, and of Professor Sherman Kent, of the history faculty, well endowed with drive and imagination and now filling an important post in the Office of the Coordinator of Information in Washington. Between them they were able to cajole a great many Yale graduates into collecting material for us at home and abroad and not even bill us for the cost of shipping. The flow of 
material from abroad, except from England and South America, has been reduced to a mere trickle, but the amount of material that comes in from various sources in this country is even today large and important. The Hoover War Library at Stanford, which had substantial funds available for the purpose, has, of course, gathered a far more comprehensive and valuable collection in this same field than we have been able to do, but Stanford is far away and various government agencies along the eastern seaboard have found the Yale collection useful in a number of ways.

\section{Exhibitions}

The Yale University Library is notable for its beautiful exhibition rooms and corridors, and we have tried to use these to contribute to a sense of unity among the various groups within the community and to encourage a feeling of identity of Yale students and New Haveners with the other peoples of the United Nations. In New Haven, as elsewhere, the war has had a tendency to create or bring to the surface a certain amount of anti-Semitism, and we have tried to counteract this by exhibitions of some of our fine collection of Judaica. About a year ago our reference librarian, Miss Pratt, arranged a fascinating exhibition in honor of the anniversary of the founding of the first Jewish synagogue in New Haven, which is still flourishing. This included material showing the contributions that Jewish residents of New Haven have made to Yale and the community. Sholem Asch participated in the opening of this exhibition. At the present time we have an exhibition in honor of the one hundredth anniversary of the birth of the great Hungarian-American Hebrew scholar,
Alexander Kohut. We have had representative collections of coins, maps, and books illustrating the contribution of England and other of the United Nations to civilization. We are planning now to have at commencement time an exhibition of books, broadsides, and manuscripts representing the growth of democracy and tolerance in the American colonies and the United States.

\section{Possible Contributions}

Turning from the actual to the possible, the question that has exercised my mind most has been whether we should use the library as an engine for propaganda, not only by encouraging the fervor of our students and townspeople ( $I$ include the latter, because the exhibitions in the library attract a great many visitors outside the immediate Yale group) for the ideals for which we are fighting, but also by engendering or intensifying hate against the peoples, governments, and arms (or any of these) of the Axis powers. Much could obviously be done along this line, especially by a judicious selection and exhibition of posters, cartoons, and pamphlets from our war collection, by a rearrangement of our open shelves of periodicals and new books to bring into prominence the current magazines and new books taking this line of approach and suppressing or obscuring the others. Having been brought up in a devoutly Christian family and educated in a Friends college, it would be painful for me to have our library contribute to the war effort in this particular fashion. But I understand that some libraries, more. especially among the public libraries, have taken action along this line, and perhaps the Yale library is not doing its full duty to the nation in not having, as yet, followed suit. It is a question which I am 
bringing up for full discussion and decision at the next meeting of the University Library Committee and it might be a useful topic of discussion for this meeting. If the question is discussed, I hope to be advised of the consensus of opinion expressed.

\section{Protection of Resources}

I have not gone into the question of the protection of the resources and users of our library from destruction by bombing, because I regard the great amount of time and thought we have given to the question at $Y$ ale as a contribution more to present and future learning than to the war effort. But certainly all would agree that there can be no more important phase of the war activity of our libraries along the eastern coast than the sound solution of this extremely disturbing and rather delicately balanced problem.

Another problem that has seriously worried us at the Yale library is to determine how far we should go in encouraging the members of our staff to give up library work for some form of direct participation in the war effort, either by joining the Army, Navy, or Marines, by going into one of the departments at Washington, or by taking employment in one of the war industries. The question has also arisen as to how much encouragement should be given to person-to-person solicitation for the purchase of United States bonds and savings stamps. The course we have taken is roughly as follows:

When any member of the staff has consulted with me or the head of a department concerning enlistment or taking a position in the government or in a war industry, we have encouraged the person to enlist or take the position. In the case of voluntary enlistment, as well as in the case of men drafted, we have assured the staff member that his job will be open for him after the war. In the case of those who have taken civilian jobs with a government department in $W$ ashington or gone into a war industry, we have not committed ourselves to take them back after the war, but I have personally assured anyone who has spoken to me about the point that we shall give precedence to staff members leaving for one of these purposes. Our numerous resignations have, of course, crippled our staff but not yet seriously enough to present an acute problem.

\section{Solicitation for Sale of Stamps and Bonds}

In the matter of person-to-person solicitation in the library, we have permitted such solicitation but hesitate to continue to do so. Although some people regard the library's willingness to permit this as a contribution to the war effort, I have my doubts on this score. Such solicitation consumes a good deal of the working time of those solicited, and my guess is that those who purchase the bonds and stamps through such solicitation would purchase substantially the same amount without solicitation. Perhaps my point of view is influenced by my conviction that capital needed for the war, like manpower, should be drafted either through taxes or enforced saving, which would make bondbuying campaigns of all kinds unnecessary.

In asking me to present this paper, Mr. Leupp suggested that I add a word about what other university libraries along the east coast are doing. I gather from conversations with several university librarians along the east coast that Yale's course has been pretty much in line with what is being done generally. Some of 
the public libraries have taken a more direct part in the war effort by putting up recruiting posters, making prominent displays of books such as the Shirer Diary and the Davies Mission to Moscow. Our general policy is not to buy more than two copies of any current book (any department that desires more than two copies buys the additional ones out of its own departmental funds), and we have so far adhered to this policy. We have given some thought in the library to the question of whether it is not our duty to use a larger proportion of our available book funds during the war for the purchase of a large number of copies of books which would instill the war spirit in the minds and hearts of the students, and by appropriate publicity induce the students to read them. This is another question that I expect to bring up at the library committee's next meeting.

\section{Longer Hours for Staff?}

The question has just been raised whether the library ought not to ask its staff to put in longer hours (without increase in pay because the university is not in a position to grant any increase), so as gradually to release more and more members of the staff for war work. The question could easily become acute at Yale, as in other colleges that have adopted the year-round curriculum, because the members of the faculty who previously had their summers free are giving courses this summer without extra pay. But, despite this consideration, I can see no justice in asking members of our library staff to make such a sacrifice when workers in industry, far from working extra hours without any pay, get a higher rate of pay for overtime than for the normal working period. 